\title{
Regionalne zróżnicowanie pochówków w Polsce
}

\author{
Maria Staszyńska \\ Uniwersytet Warszawski
}

DOI: http://dx.doi.org/10.18778/1733-8069.16.4.11

\begin{abstract}
Słowa kluczowe: Abstrakt: Celem artykułu jest analiza regionalnych i społecznych zróżnicowań pochówków. Badanie pogrzeb, pochówek, jakościowe zostało przeprowadzone w pięciu regionach - na Pomorzu Zachodnim, Podkarpaciu, Podkremacja, zakład pogrzebowy, lasiu, Podhalu oraz w Warszawie i jej okolicach. Źródłem danych do prowadzonych analiz są wywiady swobodne przeprowadzone z przedsiębiorcami pogrzebowymi i pracownikami zakładów pogrzeboprzedsiębiorca pogrzebowy, śmierć wych. Przedsiębiorcy z branży funeralnej pełnią coraz większą rolę w chowaniu zmarłych, a ponadto dysponują dogłębną wiedzą o społecznych oczekiwaniach wobec organizacji pogrzebów.
\end{abstract}

Maria Staszyńska, mgr, absolwentka Instytutu Socjologii Uniwersytetu Warszawskiego, obecnie w trakcie studiów doktoranckich na Wydziale Socjologii UW. Zainteresowania naukowe: socjologia jakościowa, metodologia badań społecznych. Prowadzi zajęcia dydaktyczne w Akademii Leona Koźmińskiego.

\section{Adres kontaktowy:}

Wydział Socjologii Uniwersytetu Warszawskiego

ul. Karowa 18, 00-927 Warszawa

e-mail: m.staszynska@is.uw.edu.pl, maria.staszynska@gmail.com

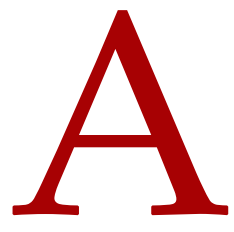

rtykuł jest próbą usystematyzowania obrzędów pogrzebowych $\mathrm{w}$ pięciu regionach Polski. Podstawą przedstawionych w nim wniosków są analizy wywiadów swobodnych z przedsiębiorcami pogrzebowymi. Pretekstem do rozmów z przedstawicielami branży funeralnej była próba zrozumienia specyfiki tego zawodu (wywiady w Warszawie i okolicach). Projekt przerodził się później w większe badanie dotyczące zróżnicowania pochówków. 
Praktyki pogrzebowe, poza oczywistą funkcją higieniczną, pozbyciem się ciała zmarłego, mają również na celu oswojenie się żałobników z faktem odejścia bliskiej osoby. Dowodem powszechnej świadomości nieuchronności śmierci są praktyki i rytuały chowania zmarłych obecne w każdej kulturze na świecie (Bauman 1998: 65).

Niewątpliwie sposoby grzebania zmarłych ewoluują. Zmiany dyktowane są przez rozmaite procesy społeczne. Wśród tych procesów na szczególną uwagę zasługują globalizacja, urbanizacja, sekularyzacja, zmiany modelu rodziny oraz rozwój medycyny. W XXI wieku w związku ze zmianami klimatu nasila się troska o środowisko naturalne, co również w długofalowej perspektywie może wpływać na sposoby obchodzenia się z ciałem po śmierci. Należy jednak mieć na uwadze, że wszystkie te wzajemnie wpływające na siebie zjawiska, a także z pewnością wiele innych, mają wpływ na przemiany praktyk pogrzebowych.

Pod wpływem globalizacji adaptowane są z Zachodu nowe akcesoria funeralne oraz nowe technologie, które przedsiębiorcy pogrzebowi chętnie dołączają do dostępnej już wcześniej oferty. Nie tylko nowe usługi, akcesoria i technologie są efektem globalizacji oraz kultury konsumpcyjnej na polskim rynku usług pogrzebowych, bowiem sam fakt przejmowania coraz większej liczby czynności wykonywanych przy zmarłym z rąk rodziny czy duchownych jest przejawem przenikania kultury funeralnej Zachodu do Polski (Kubiak 2015: 307-309).

Z całą pewnością postępująca sekularyzacja ma ogromny wpływ na przemiany pochówków poprzez zmiany postaw dotyczących śmierci i umierania. Wzrasta liczba osób, dla których śmierć przestała być przejściem na drugą stronę, do życia wiecznego, gdyż religia przestaje pełnić funkcje terapeutyczne. Również rola duchownych jako osób pomagających rodzinie uporać się z żałobą została znacznie ograniczona (Ostrowska 2005: 33). Współcześnie, szczególnie w miastach, coraz bardziej powszechnym zjawiskiem są pogrzeby świeckie, bez udziału duchownych.

Wśród przemian społecznych mających wpływ na charakter pochówków niezwykle ważna jest urbanizacja. Wzrost liczby ludności mieszkającej w miastach wraz z rozwojem medycyny, powstawaniem kolejnych hospicjów i szpitali sprawia, że coraz rzadziej ma się możliwość obcowania ze starzeniem się i śmiercią. Urbanizacji towarzyszy profesjonalizacja oraz komercjalizacja usług pogrzebowych. Czynności wykonywane dotychczas przez członków rodziny czy sąsiadów, takie jak ubieranie zmarłego i przygotowywanie do pogrzebu, a nawet wytwarzanie trumien, przejmowane są przez zakłady pogrzebowe, które oferują coraz większą liczbę usług oraz sprzedaż rozmaitych akcesoriów funeralnych (Vovelle 2008: 670; Kubiak 2015: 25-28). Urbanizacja zwiększa również tempo życia, co sprawia, że czasu na obcowanie ze śmiercią w miastach jest coraz mniej. Wraz z postępem medycyny ludzie coraz częściej umierają nie w domu, lecz w szpitalu, co oznacza, że społeczność coraz bardziej odgradzana jest od śmierci (Vovelle 2008: 657). Obok procesów urbanizacji na postawy wobec umierania ma wpływ również wzrost liczby rodzin nuklearnych. Odseparowanie młodszych od starszych pokoleń znacznie ogranicza możliwość obserwacji naturalnych zmian związanych ze starzeniem się i umieraniem (Ostrowska 2005: 33-34). Postęp medycyny również przyczynia się do usuwania śmierci ze świadomości społecznej; umieranie przenosi się z domu do szpitala. Przy odchodzącej osobie nie czuwa już cała rodzina, 
nie odwiedzają jej sąsiedzi, bardzo często grono to kurczy się do kilku osób. Bywa, że sam umierający lub towarzyszący mu dorośli nie zgadzają się na odwiedziny dzieci. Również pogrzeb staje się wydarzeniem coraz bardziej prywatnym, zarezerwowanym dla kręgu rodziny i bliskich znajomych (Ariés 2011: 575).

W kulturze europejskiej ludzie mający kontakt ze zwłokami czy grabarze traktowani są jako swoiście wykluczeni. Nie akceptuje się ich łatwo w codziennej przestrzeni społecznej. Przedsiębiorcy z branży funeralnej często spotykają się z odruchem odrazy u osób, które dowiadują się o charakterze ich pracy. Zdarza się, że niektórzy nie chcą podać im ręki na przywitanie. Praca ta naznaczona jest tabu śmierci. Samo mieszkanie w sąsiedztwie zakładu pogrzebowego czy krematorium często budzi sprzeciw. Jak pisze di Nola (2006: 164), w wielu miejscach na świecie czynności związane $\mathrm{z}$ bezpośrednim chowaniem zmarłych do ziemi traktowane były jako tak nieczyste, że nie zlecano ich nawet osobom z najniższych warstw społecznych. W Polsce dochodzi do tego jeszcze stereotyp pochodzacy z czasów PRL-u. Istniało wówczas tylko jedno komunalne przedsiębiorstwo usług pogrzebowych, z którego pracownikami każdy chowający członka rodziny musiał obcować. Powszechne były poglądy o niekompetencji pracowników tego przedsiębiorstwa, krążyły historie o pijanych grabarzach wpadających do dołu razem z trumną. Wiele $\mathrm{z}$ tych opinii przetrwało do dzisiaj, chociaż często takie przekonania i sądy są krzywdzące dla pracowników domów pogrzebowych. Niektórzy z nich czują się dyskryminowani przez państwo i społeczeństwo, bowiem chcieliby być postrzegani jako zwyczajni ludzie, tacy jak wszyscy inni, realizujący ważną i potrzebną społeczeństwu funkcję.

\section{Społeczne funkcje pogrzebów}

Współczesne pogrzeby spełniają szereg ważnych funkcji społecznych (poza tym, że pełnią oczywistą funkcję pozbycia się ciała zmarłego). Antonina Ostrowska (2005: 235-247) opisywała pogrzeby, wykorzystując podział Mertona na funkcje jawne i ukryte. „Te pierwsze odnoszą się do tych obiektywnych skutków dla określonej jednostki (osoby, podgrupy, systemu kulturalnego czy społecznego), które się przyczyniają do jej adaptacji i korygowania, a które zostały w tym celu pomyślane. Te drugie - odnoszą się do tego samego typu skutków, ale niezamierzonych i niedostrzeganych" (Merton 2002: 122-133).

Funkcje jawne pogrzebu to zabiegi higieniczne mające związek z koniecznością pozbycia się ciała oraz zabiegi religijne czy magiczne mające na celu przeprowadzenie duszy do życia pozaziemskiego. Do ukrytych należy zaliczyć funkcję terapeutyczną dla rodziny oraz znajomych zmarłego, tak jak i inne funkcje społeczne, na przykład zademonstrowanie pozycji społecznej zmarłej osoby przez wygląd, przepych i rozmiar ceremonii (Ostrowska 2005: 235-236), a także wybór cmentarza czy miejsca na cmentarzu. Fakt, że cmentarzy jest tak wiele, świadczy nie tylko o dużej liczbie różnych wyznań religijnych, ale również o statusie majątkowym czy społecznym zmarłych (Gajewska 2009: 135). Niektóre cmentarze są bardziej prestiżowe od innych, tak jak na przykład Cmentarz Powązkowski w Warszawie z Aleją Zasłużonych, gdzie spoczywają zmarli artyści, pisarze, malarze oraz przedstawiciele inteligencji. Istotną funkcją społeczną pogrzebów jest również funkcja integracyjna. Jako przykład mogą tu posłużyć pogrzeby osób publicznych transmitowane w telewizji i Internecie. Taką doniosłą rolę integracyjną odegrały pochówki ofiar katastrofy 
samolotu TU-154 w Smoleńsku, w której zginęło 96 osób, w tym para prezydencka i wielu znanych polityków. Pogrzeb ten bez wątpienia (przynajmniej na chwilę) przyczynił się do wzmocnienia tożsamości narodowej Polaków i zjednoczył cały kraj bez względu na istniejące podziały polityczne. Warto również zwrócić uwagę na korzystne dla społeczeństwa ukryte funkcje kremacji, które zapobiegają przepełnieniu cmentarzy, są stosunkowo mniej kosztowne i mniej szkodliwe dla środowiska.

Pogrzeby praktycznie we wszystkich kulturach mają być nie tylko godnym pożegnaniem zmarłego, afirmacją jego życia, ale pełnią ważniejsze funkcje ukryte - są organizowane dla żywych. Mają ułatwić rozstanie z ukochaną osobą, przyspieszyć naturalny proces żałoby poprzez akceptację faktu śmierci. Często mówi się, że pogrzeb jest dla żywych, dlatego sposób obchodzenia się z ciałem często jest ważniejszy dla rodziny niż dla samego zmarłego. To rodzina odwiedza zmarłego na cmentarzu, dlatego to ona decyduje (chyba że zmarły zostawił dyspozycje), w jaki sposób będzie pochowany, czy będzie to pochówek z urną, czy z trumną, jak będzie wyglądała oprawa pogrzebu, czy będzie on skromny, czy nie. Często decydują o tym względy finansowe czy praktyczne, ale także tradycja, wiara czy przekonania i wyobrażenia na temat obu rodzajów pochówków.

Najbardziej powszechnym rodzajem pogrzebu w Polsce jest nadal pogrzeb tradycyjny, czyli z trumną, w obrządku katolickim (Kubiak 2015: 177-178). Trudno oszacować liczbę pogrzebów świeckich, nie zbiera się niestety takich statystyk. Z badań Anny E. Kubiak wynika, że pochówki bezwyznaniowe w Polsce stanowią od 2 do $5 \%$ ceremonii pogrzebowych, a samych mistrzów ceremonii jest około 20 w całej Polsce, przy czym doświadczonych i wy- specjalizowanych w zawodzie jest jedynie 6 osób, co oddaje skalę tego zjawiska (Kubiak 2015: 223). Niewątpliwie skutkiem przemian społecznych w naszej kulturze jest zwrot $\mathrm{w}$ stronę kremacji, które mimo tego, że wciąż nie są najczęstszą metodą pochówku w Polsce, stają się coraz bardziej popularne1. Niektóre osoby już za życia zostawiają rodzinie instrukcje dotyczące pogrzebu z urną. Jest to decyzja bardzo często podyktowana względami praktycznymi, kremacja jest stosunkowo tanim sposobem pozbycia się zwłok, zmniejsza również przepełnienie cmentarzy, ponieważ urnę można "dochować" do istniejącego już grobu, a zajmuje ona znacznie mniej miejsca niż trumna. Nie bez znaczenia jest również strach przed gniciem w trumnie, w tym przypadku kremacja jest wyraźnym wyrazem pragnienia ucieczki od rozkładu. Ogień jako instrument oczyszczenia daje gwarancję uniknięcia gnicia. Prochy są również bezpieczne dla środowiska (Thomas 1991: 190). W porównaniu do możliwości pochówku, jakie przewiduje prawo w niektórych krajach (np. zamiana prochów w diament, pochówki kosmiczne czy cmentarze - lasy z drzewami rosnącymi na prochach zmarłych) (Gajewska 2009: 114-121), w Polsce $\mathrm{w}$ dalszym ciągu dozwolone są jedynie pogrzeby z trumną oraz kremacyjne. Zgodnie z Ustawą z dnia 31 stycznia 1959 r. o cmentarzach i chowaniu zmarłych należy pochować prochy do grobu, kolumbarium² ${ }^{2}$ lub rozsypać na polu pamięci w konkretnym, wyznaczonym do tego miejscu (Dz.U. 1959 nr 11

\footnotetext{
${ }^{1}$ Może to być także efektem rosnącej liczby krematoriów. W 2012 r. było ich w Polsce 18, w 2014 - 30 (Kubiak 2015: 196), a obecnie - 65 (dane ze strony http://www.polskiestowarzyszeniepogrzebowe.pl/pl/Lewe-menu/Krematoria-w-Polsce-Wykaz [dostęp 1.10.2020]). W badanych regionach liczba krematoriów przedstawia się następująco: Warszawa i woj. mazowieckie - 7, Pomorze Zachodnie - 3, Małopolska - 1, Podlasie - 3 i Podkarpacie - 2 (zob. https://krematoria.com.pl [dostęp 1.10.2020]).

${ }^{2}$ Kolumbarium to naziemna budowla, ściana $\mathrm{z}$ miejscem na prochy w ściennych niszach, zbiorowy grobowiec, w którym chowa się urny z prochami zmarłych.
} 
poz. 62). Niestety nie prowadzi się dokładnych statystyk kremacji, takich danych nie zbiera Główny Urząd Statystyczny. Zajmują się tym jednak stowarzyszenia pogrzebowe, na przykład Polska Izba Pogrzebowa czy Polskie Stowarzyszenie Pogrzebowe. Dane te mają jednak charakter szacunkowy i pochodzą głównie z krematoriów komunalnych. Według prezesa Polskiego Stowarzyszenia Pogrzebowego w 2016 roku w Warszawie kremacje stanowiły 32$35 \%$, a w innych dużych miastach, takich jak Szczecin czy Wrocław, około 38-40\% pochówków. Dla porównania: w Szwecji, Szwajcarii, Danii, Słowenii czy w Czechach kremacji dokonuje się w około 80\% lub więcej przypadków ${ }^{3}$. Przyczyną wciąż małej popularności tego rodzaju radzenia sobie ze zwłokami w Polsce może być również niechęć Kościoła katolickiego do odprawiania mszy nad urną, przywiązanie do tradycyjnych pogrzebów z trumną (zwłaszcza na wsi) oraz złe skojarzenia, szczególnie obecne w starszym pokoleniu, z piecami krematoryjnymi z obozów koncentracyjnych (Kubiak 2015: 200).

\section{Metodologia}

W artykule opisuję pogrzeby z perspektywy osób zajmujących się zawodowo chowaniem zmarłych, przedsiębiorców i pracowników zakładów pogrzebowych z trzech powodów. Po pierwsze, wywiady ze specjalistami od pochówków pozwoliły mi na ograniczenie próby, ponieważ pogrzebownicy to osoby posiadające rzetelne informacje o występujących w regionie, w którym oferują swoje usługi, sposobach grzebania zmarłych. Było to łatwiejsze niż kontakt z wieloma osobami uczestniczącymi w pogrzebach rodzinami czy znajomymi zmarłych. Po drugie, są to osoby, które od jakiegoś czasu są niezbędnymi akto-

\footnotetext{
3 Zob. https://centrum-pogrzebowe.pl/kremacja-w-polsce-na-tle-swiatowych-statystyk/ [dostęp 1.10.2020].
}

rami ceremonii pogrzebowej, dlatego rekonstrukcja ich punktu widzenia oraz relacji z rodziną zmarłego i duchownymi wydaje mi się niezbędna w opisie współczesnych zwyczajów funeralnych. Po trzecie, zawód przedsiębiorcy pogrzebowego jest sam w sobie interesujący z punktu widzenia badacza ze względu na jego specyficzne usytuowanie społeczne.

Wnioski przedstawione $\mathrm{w}$ tym artykule są wynikiem badania jakościowego przeprowadzonego na niewielkiej, celowo dobranej próbie przedsiębiorców pogrzebowych oraz innych osób związanych z organizacją pogrzebów w pięciu regionach Polski. Wywiady swobodne zostały zrealizowane od sierpnia 2016 roku do lutego 2017 roku na Pomorzu Zachodnim, Podkarpaciu, Podlasiu oraz Podhalu ${ }^{4}$.

Celem badań była rekonstrukcja regionalnych oraz społecznych zróżnicowań pochówków. W rezultacie przeprowadziłam 15 wywiadów swobodnych z przedsiębiorcami z branży funeralnej lub pracownikami zakładów pogrzebowych, jeden wywiad ze śpiewaczką pogrzebową, jeden wywiad z księdzem prawosławnym, jeden z imamem oraz jeden z księdzem katolickim ${ }^{5}$.

$\mathrm{W}$ artykule wykorzystuje ponadto materiały z badania przeprowadzonego przeze mnie w 2015 roku na próbie celowej przedsiębiorców z branży fune-

\footnotetext{
${ }^{4}$ Wyjazdy badawcze zostały częściowo sfinansowane dzięki dotacji na badania jakościowe z Instytutu Socjologii Uniwersytetu Warszawskiego. Wyniki badania zostały szerzej omówione w pracy magisterskiej przygotowanej pod kierunkiem dr hab. Prof UW Mirosławy Grabowskiej w Instytucie Socjologii Uniwersytetu Warszawskiego pt. Impares nascimur, pares morimur. Społeczne zróżnicowania form pochówku oraz pracy licencjackiej przygotowanej pod kierunkiem dr. hab. prof. ALK Piotra Chmielewskiego w Akademii Leona Koźmińskiego pt. Jak zarobić na śmierci? Komercjalizacja usług pogrzebowych.

${ }^{5}$ Ze względu na fakt, iż skupiam się głównie na pogrzebach katolickich i świeckich, oraz niewielką przydatność informacji pochodzących z wywiadów z duchownymi, postanowiłam tych wywiadów nie wykorzystywać.
} 
ralnej z Warszawy i jej okolic, które miało funkcje eksploracyjne. Umożliwiło bowiem zrekonstruowanie wzorów funkcjonowania tych przedsiębiorców $\mathrm{w}$ ich instytucjonalnym środowisku, ich otoczenia organizacyjnego, a także wzorów dostosowywania działalności do społecznych oczekiwań ich klientów. W wywiadach pojawiały się jednak także wypowiedzi dotyczące zróżnicowania pogrzebów w Warszawie i okolicach, dlatego zdecydowałam się wykorzystać je w tym artykule. Łącznie przeprowadziłam 26 indywidualnych wywiadów pogłębionych.

Ze względu na to, że grupa, której dotyczy badana tematyka, czyli właściwie wszyscy ludzie, którzy w jakiś sposób uczestniczą w pogrzebach, jest zbyt duża, żeby należycie ją zbadać metodami jakościowymi, postanowiłam potraktować przedsiębiorców z branży funeralnej przede wszystkim jako kompetentnych informatorów, ale także jako "odźwiernych”. Założyłam, że właściciele firm pogrzebowych $\mathrm{w}$ poszczególnych regionach będą mieli doskonałą wiedzę o zwyczajach panujących na obsługiwanym przez nich obszarze, a sami w jakiś sposób mogą przyczyniać się do przemian pochówków. W ten sposób uzyskałam charakterystykę ceremonii pogrzebowych w czterech regionach Polski, przeprowadzając niewielką liczbę wywiadów w każdym z nich (Hammersley, Atkinson 2000: 73-77). Badanie jakościowe było pomyślane jako eksploracyjne, dające wstępne rozpoznanie zróżnicowania pochówków, aby w przyszłości wnioski płynące z tego badania umożliwiły postawienie hipotez, które zostałyby zweryfikowane w badaniu reprezentatywnym (Merton 1987: 557-558; Morgan, Fellows 2008: 340-347).

Zdecydowałam się na przeprowadzenie badania w czterech regionach: na Pomorzu Zachodnim, Podlasiu, Podhalu oraz na Podkarpaciu. Wykorzystałam także wywiady przeprowadzone we wstępnym badaniu w Warszawie i okolicach. Dobór tych regionów miał charakter celowy; brałam pod uwage poziom urbanizacji, religijność, stopień zakorzenienia ludności oraz strukturę narodowościową i wyznaniową ${ }^{6}$. W każdym z regionów przeprowadziłam wywiady w dużym mieście, mieście średniej wielkości oraz na wsi.

Można podzielić Polskę na regiony mniej i bardziej tradycyjne (co wiąże się również z religijnością), regiony „zasiedziałe", które charakteryzują się względnie stabilną populacją, której struktury nie zmieniły wydarzenia historyczne i takie, których populacja kształtowała się na nowo w wyniku II wojny światowej. Do tych pierwszych można zaliczyć Podlasie, Podkarpacie i Podhale, gdzie wojna nie spowodowała zasadniczych zmian w strukturze populacji. Inaczej rzecz się miała na Pomorzu Zachodnim i w Warszawie. Pomorze Zachodnie weszło w skład Polski dopiero po wojnie i było zasiedlane przez osadników, przede wszystkim z Kresów Wschodnich, ale także z innych części Polski. Społeczność Pomorza Zachodniego po wysiedleniu ludności niemieckiej kształtowała się zatem na nowo. Warszawa, niemal całkowicie zburzona po Powstaniu Warszawskim, po wyzwoleniu także zaludniała się na nowo; wielu dawnych mieszkańców już do niej nie wróciło, a przybyli mieszkańcy różnych regionów Polski. Rzecz jasna, Warszawa i jej okolice nie reprezentują całego Mazowsza, które jest wyraźnie zróżnicowane. Niemniej jednak wywiady przeprowadzone w Warszawie dają istotny wkład do wiedzy o pogrzebach; dlatego właśnie zdecydowałam się włączyć materiał w nich zgromadzony do niniejszej analizy.

Poniższa tabela pokazuje charakterystykę regionów, w których robiłam badania.

\footnotetext{
${ }^{6}$ Wyjaśnienie poszczególnych kryteriów doboru regionów znajduje się w przypisach do tabeli 1 .
} 
Tabela 1. Charakterystyka badanych regionów

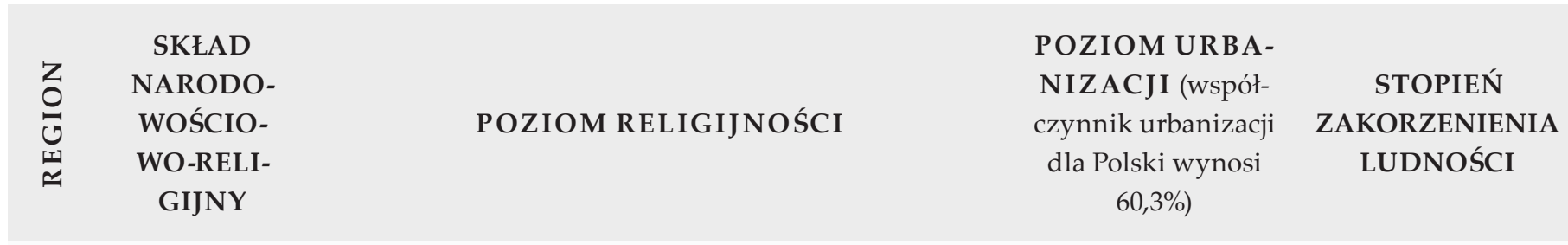

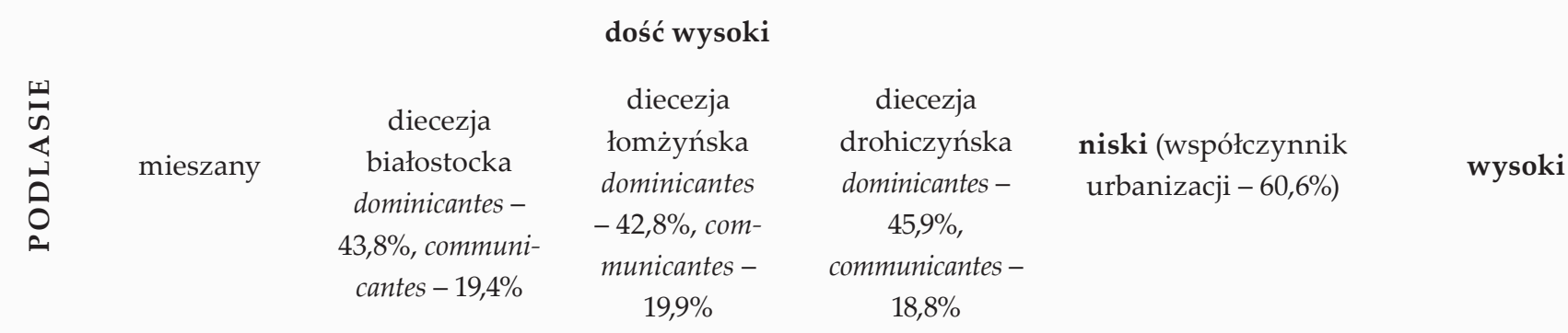

\begin{tabular}{ccc} 
historycznie & \multicolumn{2}{c}{ wysoki } \\
mieszany, & diecezja rzeszowska & diecezja przemyska \\
dominicantes $-64,6 \%$, & dominicantes $-59,6 \%$, \\
communicantes $-18,1 \%$ & communicantes $-16,5 \%$
\end{tabular}

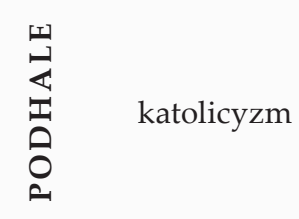

wysoki

diecezja krakowska
dominicantes - 50,7\%,
communicantes $-17,7 \%$

niski (współczynnik urbanizacji - 41,3\% najniższy w Polsce) niski (współczynnik urbanizacji dla województwa małopolskiego $-48,5 \%$, dla powiatu tatrzańskiego $-40,4 \%$, dla powiatu nowotarskiego $-27,5 \%)$
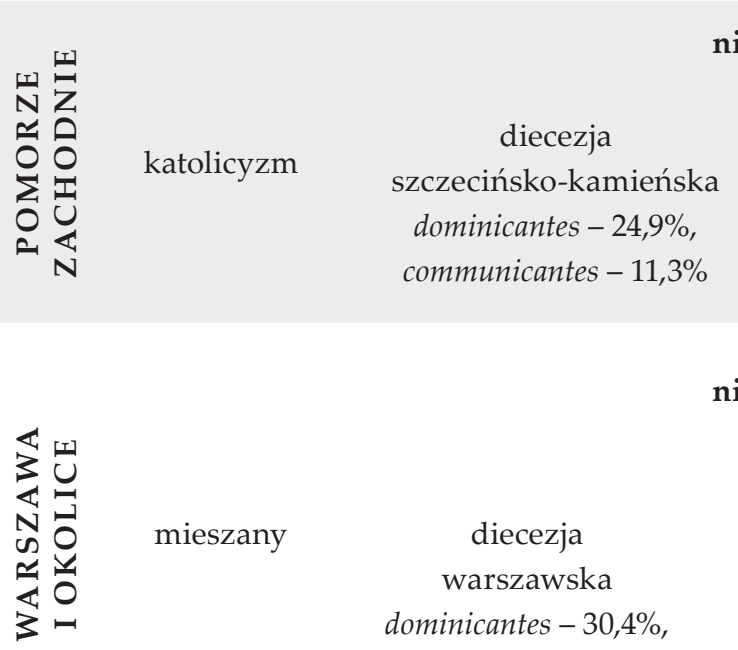

niski
diecezja koszalińsko-białobrzeska dominicantes - $25,8 \%$ communicantes - $10,8 \%$
średni
(współczynnik urba- (zasiedlanie po nizacji $-68,6 \%$ II wojnie światowej)

\section{niski}

diecezja
warszawsko-praska
dominicantes $-31,4 \%$
communicantes $-14,3 \%$

\section{bardzo wysoki}

diecezja dominicantes - 30,4\%, communicantes $-16,6 \%$

\section{niski}

(wymieszanie populacji po II wojnie światowej, wysoki poziom migracji po transformacji ustrojowej ze względu na dostępność i atrakcyjność miejsc pracy)

Źródło: opracowanie własne. 


\section{Wyniki}

\section{Pomorze Zachodnie}

Mieszkańców Pomorza Zachodniego charakteryzuje dość niska religijność, co może mieć znaczący wpływ na skrócenie czasu przeznaczonego na ostatnie pożegnanie bliskich. Według statystyk Kościoła katolickiego w 2014 roku w diecezji szczecińsko-kamieńskiej odnotowano $24,9 \%$ dominicantes $\left(11,3 \%\right.$ communicantes $\left.^{7}\right)$, a w koszalińsko-kołobrzeskiej $25,8 \%$ dominicantes (10,8\% communicantes), co należy do zdecydowanie najniższych odnotowanych w roku 2014 wyników (Instytut Statystyki Kościoła Katolickiego [ISKK] 2014). W większych miastach na Pomorzu Zachodnim pogrzeby są zdecydowanie krótsze niż we wsiach czy małych miejscowościach. Pracownicy zakładów pogrzebowych mówili o pogrzebach w Szczecinie, jak o czymś wykonywanym szybko i na masową skalę, porównując je czasem nawet do masowej produkcji taśmowej. Okazuje się jednak, że we wsiach i mniejszych miejscowościach w dalszym ciągu pogrzeb może być wydarzeniem skupiającym uwagę całej społeczności. Wydaje się, że czasu poświęconego na zadumę nad zmarłym jest tym więcej, im mniejsza jest miejscowość; nie oznacza to jednak, że w małych miejscowościach nie da się zauważyć tendencji zbliżania się do obyczajów miejskich. Już w tej chwili ludzie bardzo często decydują się na kremację z prozaicznej przyczyny, czyli braku miejsca na cmentarzu. Urna zajmuje znacznie mniej miejsca, co oznacza, że można „dochować $^{8 \prime \prime}$ wiele urn do istniejącego już grobu. Ma

${ }^{7}$ Co roku Instytut Statystyki Kościoła Katolickiego przeprowadza badanie praktyk religijnych Polaków. Wskaźniki communicantes i dominicantes oznaczają odpowiednio odsetek przyjmujących komunię podczas niedzielnej mszy oraz odsetek obecnych na tej samej mszy wiernych.

8 „Dochowanie" to określenie typowe dla języka przedsiębiorców pogrzebowych. to znaczenie szczególnie ze względu na prestiż niektórych cmentarzy, a co za tym idzie, niechęć do kupowania miejsc na innych. Na przykład Cmentarz Centralny w Szczecinie jest traktowany jako bardzo prestiżowe miejsce, niemal tak samo jak Cmentarz Powązkowski w Warszawie. Kwatery na takich cmentarzach są albo bardzo drogie, albo po prostu ich już nie ma. Wydaje się, że z kolei na wsiach miejsce ma o wiele mniejsze znaczenie, wybór pogrzebu z trumną zamiast kremacji jest niemalże oczywisty. Cmentarz Centralny w Szczecinie dysponuje również miejscem na rozsypanie prochów, tak zwanym polem pamięci. Nie oznacza to jednak, że pochówki z urną przeważają nad pochówkami z trumną; z relacji przedsiębiorców pogrzebowych wynika, że kremacje w Szczecinie to około 50\% wszystkich pogrzebów. „W tej chwili 50\% pogrzebów to kremacje" (wywiad 1, Pomorze Zachodnie, duże miasto). „Większość to urna, kremacje” (wywiad 3, Pomorze Zachodnie, duże miasto). Głównym motywem wyboru kremacji są względy finansowe oraz możliwość dochowania urny do istniejącego już grobu.

Brak miejsca. Cmentarz Centralny już robi się zamknięty. Dochowania tylko i nieopłacone groby są likwidowane. Więc jak ktoś chce mieć swoich bliskich na cmentarzu, to nie ma wyjścia. Czasem to powoduje, bo skremować można, ile się chce i dochować do grobu. [wywiad 2, Pomorze Zachodnie, duże miasto]

Głównie finansowych, ale nie tylko. Nasz cmentarz jako taki już się skończył, miejsca są, ale na zasadzie pozyskiwania starych nieopłaconych grobów i tylko takie na Cmentarzu Centralnym są. Mamy drugi cmentarz na Bronowickiej, ale ludzie nie chca, wolą ten cmentarz. [wywiad 1, Pomorze Zachodnie, duże miasto]

Z kolei w mniejszych miejscowościach i wsiach na Pomorzu Zachodnim kremacji jest zdecydowa- 
nie mniej niż w miastach. Według przedsiębiorcy pogrzebowego ze średniej wielkości miejscowości kremacji jest około $5 \%$, ale jest to coraz częstsza praktyka.

Kremacje są coraz powszechniejsze, ale ich - tych kremacji - jest, no tak jak, póki co, nie więcej jak, tak jak na naszym terenie to z $5 \%$. (...) W dużych miastach to jest więcej, to wymuszone jest tym, że na tych cmentarzach nie ma miejsc. [wywiad 4, Pomorze Zachodnie, miasto średniej wielkości]

W Szczecinie pogrzeb często nazywany jest „masówką". Upowszechniły się ceremonie raczej skromne, bez względu na zasobność portfela zmarłego i jego rodziny. Przedsiębiorcy pogrzebowi często wspominali, że dla nich wszystkie pogrzeby wyglądają tak samo, bez względu na to, kim zmarły był. Znacznie skrócił się też czas ceremonii. Wystawienie zwłok ogranicza się do pół godziny, po którym następuje odprowadzenie na cmentarz. Rodzina ma zwykle około 15 minut na pożegnanie się ze zmarłym.

Wszystko jest na czas. Przychodzi się o godzinie, jest wyjście, to wszystko jakby reguluje zachowanie ludzi, którzy być może inaczej by się zachowywali, gdyby można było też inaczej. A to jakby zmusza, przychodzimy na 15, do 15:15 jest czas, potem trzeba wyjść, to wszystko jakby z zegarkiem w ręku, chore to troszeczkę jest, ale taka jest prawda. [wywiad 3, Pomorze Zachodnie, duże miasto]

Wystawienie w kaplicy na Cmentarzu Centralnym trwa pół godziny i te pierwsze 15 minut tego wystawienia jest zawsze dla rodziny, jest czas, żeby pomyśleć, pomodlić się, a na drugie piętnaście minut wystawienia przychodzi ksiądz, odprawia egzekwia przy trumnie i wyprowadza trumnę z kaplicy i jest już wyprowadzenie do grobu do miejsca pochówku. [wywiad 1, Pomorze Zachodnie, duże miasto]

W mniejszych miejscowościach czas spędzany przez rodzinę przy zmarłym również się skraca, ale jest jednak dłuższy niż w miastach. Dzień przed ceremonią pogrzebową często rodzina zbiera się przy zmarłym na czuwanie w kaplicy.

To czuwanie jest jakby, przeniosło się to już do kaplicy, że jest kaplica na cmentarzu i to czuwanie w kaplicy jest tam dzień przed pogrzebem. Przeważnie dzień. Wcześniej było tak, że do pogrzebu codziennie tam po południu przychodzili ludzie i była ta trumna wystawiona, i ona była wystawiona, od rana do nocy stała w tej kaplicy. Kto chciał, ile razy chciał, przychodził. Nie było chłodni, nie było niczego... [wywiad 4, Pomorze Zachodnie, miasto średniej wielkości]

Pogrzeby świeckie zdarzają się stosunkowo rzadko. Wśród moich rozmówców panowało przekonanie, że nie są one efektem braku wiary, ale raczej nieporozumienia z księdzem, szczególnie w małych miejscowościach, w których kontakty z duchownymi mogą być częstsze niż w dużych miastach.

Jest, często jest tak, że ten różaniec i tak się odbywa, że krzyż nad takim grobem też stoi, że to nie jest pozbawione wartości jakichś tam religijnych, tylko po prostu sobie ktoś ze względu na coś nie życzy tego księdza. On jest wierzący, ale księdzu nie zaufał tam na tyle, żeby pozwolić, żeby go tam pochował. [wywiad 4, Pomorze Zachodnie, miasto średniej wielkości]

Na Pomorzu Zachodnim daje się zauważyć rosnącą popularność kremacji, szczególnie w miastach, oraz skrócenie czasu przeznaczonego na pożegnanie najbliższych ze zmarłymi. Również w mniejszych miejscowościach, wciąż dużo bardziej tradycyjnych 
w porównaniu z miastami, daje się zauważyć pewne oznaki odchodzenia od tradycji i skrócenie czasu pożegnania. Można zaryzykować stwierdzenie, że taki zwrot w stronę mniej tradycyjnych pochówków jest po części związany z mniejszą religijnością społeczeństwa zamieszkującego ten region (w porównaniu na przykład z Podkarpaciem), historią tego obszaru, którego społeczność tworzyła się po II wojnie światowej na nowo, o czym sami przedsiębiorcy pogrzebowi wielokrotnie wspominali pytani o wspólne, charakterystyczne dla Pomorza Zachodniego zwyczaje pogrzebowe i tradycje. Z relacji moich respondentów wynika, że przez wielką liczbę osadników przybyłych z innych części kraju w tym regionie społeczność nie była na tyle mocno ze sobą związana, żeby wykształcić jakieś wierzenia czy tradycje wspólne i charakterystyczne dla całego obszaru Pomorza Zachodniego lub jego poszczególnych części. Jest to również region ze stosunkowo dużą liczbą mieszkańców miast (około 70\% ogółu ludności tego województwa mieszka w miastach) (Urząd Statystyczny w Szczecinie 2016), co może mieć wpływ na upowszechnienie się kremacji i odchodzenie od dawnych zwyczajów na korzyść krótszych pogrzebów.

\section{Podlasie}

Podlasie jest specyficznym regionem ze względu na głęboko zakorzenione tradycje oraz przemieszanie mieszkańców różnych wyznań (katolicy, prawosławni, muzułmanie), ich wierzeń i zwyczajów. Mieszkańców Podlasia charakteryzuje również wysoka religijność, co może mieć znaczący wpływ na sposób postępowania ze zmarłymi. W 2014 roku w diecezji białostockiej odsetek dominicantes wyniósł 43,8\% (a communicantes 19,4\%), w diecezji łomżyńskiej - 42,8\% (a communicantes 19,9\%), zaś w diecezji drohiczyńskiej dominicantes było 45,9\% (a communicantes 18,8\%) (ISKK 2014). W podlaskich większych miastach (w miastach - różnej wielkości - województwa podlaskiego w 2015 roku mieszkało 61\% ludności województwa) zdarza się jeszcze trzydniowe czuwanie przy zmarłym. Jeśli nie trwa trzy dni, to w połowie przypadków, w miastach, odbywa się przynajmniej dzień wcześniej. Według moich respondentów na Podlasiu jest również bardzo mało kremacji (w Białymstoku było około 5\%, w tej chwili odsetek ten zwiększył się do około 7\%). Jest to również region charakteryzujący się bardzo dużym wpływem Kościoła na życie społeczne, co zapewne ma też znaczący wpływ na małą liczbę kremacji. Na Podlasiu przedsiębiorcy funeralni dostosowują się do panujących tradycji i dostosowują do nich swoje domy pogrzebowe. Na przykład czuwanie nad zmarłym w dalszym ciągu bywa długotrwałe, ale coraz częściej przenosi się z domu rodzinnego do domu pogrzebowego, który na ogół nie jest w stanie zapewnić rodzinie warunków podobnych do panujących w domu. Przedsiębiorcy pogrzebowi z Podlasia nie przejmują jednak większości funkcji z rąk duchownych. Księża odgrywają tutaj bardzo dużą rolę. Na Podlasiu widać wyraźną przewagę pochówków z trumną. Kremacje często są odrzucane również z powodów finansowych, dopiero od niedawna w Białymstoku funkcjonuje krematorium, co znacznie zmniejszyło koszty kremacji (dawniej wysokie, gdyż związane z koniecznością dowozu ciała do odległych krematoriów). Warto wspomnieć, że budowa krematorium wywołała protesty mieszkających w pobliżu mieszkańców (popierane przez władze miasta), którzy nie godzili się na popielenie zwłok w pobliżu ich domostw.

Słabo, znaczy jest więcej niż było i tu zasługa krematorium, które powstało w Białymstoku. Bardzo dużo ludzi przekonuje się do kremacji, już nawet sobie liczą, że to nie są takie duże koszty. Trzeba pamiętać, że 
przepisy prawa kanonicznego poprzez zachowanie pewnego tradycyjnego rytuału pochówku doprowadzają do zwiększenia kosztów (...), jeżeli prawo kanoniczne nakazuje mszę nad ciałem, a następnie kremację, to tak naprawdę mamy tradycyjny pogrzeb do zakończenia mszy świętej, następnie kremację, czyli dodatkowy koszt. Oczywiście są też oszczędności $\mathrm{w}$ postaci mniejszych opłat za miejsce czy też możliwości skorzystania większej ilości pochówków w jednym miejscu. (...) było mniej niż 5\%, około trzech do czterech, obecnie około 7\% w ciągu dwóch lat. [wywiad 14, Podlasie, duże miasto]

Kremacje powoli wchodza, ale nie jest ich za dużo, jest w Wyszkowie krematorium, nie leży to w naszej tradycji. Myślę, że pokolenie, które umiera, 80-latków, 90-latków o kremacji nie słyszeli, następne pokolenia rozważają słyszy się, że chcieliby być skremowani. Jest też kwestia kosztów, duże miasta mają miejsca na cmentarzach bardzo drogie, u nas dzierżawa miejsca na 20 lat kosztuje 200 zł. (...) Sama kremacja nie jest droga, 680 zł kosztuje w tej chwili w Wyszkowie, plus dowóz i inne akcesoria, urna. (...) Jesteśmy na Podlasiu bardzo tradycyjni. (...) Tu na Podlasiu mieszkają ludzie z dziada pradziada, pszenica i kartofle rosła na prochach dziadów i pradziadów, tam ludzie się mieszali, oni są napływowi, nie są związani z tą ziemią. Dla kogoś takiego jest łatwiej, bo sam przyszedł, zmienił miejsce zamieszkania. [wywiad 15, Podlasie, miasto średniej wielkości]

W Białymstoku czas czuwania zwykle ograniczony jest do dnia przed pogrzebem lub nawet czasem ma miejsce dopiero $w$ dniu pochówku. Zdarza się jeszcze niekiedy, zwykle u starszych osób, trzydniowe czuwanie. Jest to jednak coraz rzadszy zwyczaj, głównie ze względów praktycznych, ponieważ większość ludzi mieszka w blokach, co utrudnia wniesienie i trzymanie trumny w mieszkaniu. Z kolei na wsi czuwanie jest w dalszym ciągu praktykowane. Teoretycznie trwa 3 dni, jednak, również ze względów praktycznych, ten czas często skraca się do 2-2,5 dnia.

Właśnie nie, to się zmienia, to głównie wieś to celebruje. To wynika z tradycji życia, ciało powinno być pochowane trzy dni po, myślę, że ludzie sugerowali się kiedyś Pismem Świętym, a ta tradycja jest tylko na wsi. W mieście bardzo rzadko się zdarza, czasami u osób starszych, które jeszcze nie wyzbyły się tradycji wiejskich, ale to też ma wymiar praktyczny. Na wsi jak ktoś umiera, nasza usługa z dowozem, to znaczy przyjeżdżamy, przygotowujemy ciało, organizujemy wystawienie i rodzina zostaje z osobą zmarłą. To też jest takie oszukiwane trzy dni, bo biorąc pod uwagę pracę lekarzy, zazwyczaj są to godziny popołudniowe, jeśli zgon nastąpił rano, następnego dnia jest pełna doba czuwania i trzeciego dnia z rana następuje pochówek. Należy pamiętać, że trzy dni to jest taki średni czas na organizację, czas na wyrobienie dokumentów medycznych, prawnych. One są podstawą do zgłoszenia pochówku zarówno w parafii, jak i na cmentarzu, przygotowania grobu, dania możliwości rodzinie na przybycie, żeby pożegnać zmarłego. Jeżeli chodzi o miasta, pochówek jest zazwyczaj na trzeci dzień, ale czuwanie odbywa się zazwyczaj dzień wcześniej, a już nawet $50 \%$ to $\mathrm{w}$ dniu pochówku, czyli trochę jak w zachodniej Polsce, jak wystawienia ograniczają się do krótkiego czasu. [wywiad 14, Podlasie, duże miasto]

Charakterystyczne dla Podlasia, szczególnie dla miast mniejszych od Białegostoku, jest również budowanie przy domach pogrzebowych kaplic, żeby czuwanie, które wciąż w wielu przypadkach trwa trzy dni i odbywa się w domu z trumna, można było przenieść do kaplicy w domu pogrzebowym. Jeden $\mathrm{z}$ respondentów tłumaczył różnicę między domem pogrzebowym a zakładem pogrzebowym. Dom pogrzebowy jest miejscem, które ma być przyjazne dla rodziny, która w końcu przez kilka dni będzie do niego przychodzić 
i żegnać się ze swoim bliskim. Na takie czuwanie, w domu lub w kaplicy, przychodzi rodzina, znajomi, sąsiedzi, przychodzą również osoby, głównie kobiety, które śpiewają na pogrzebach, niekoniecznie blisko związane z osobą zmarłą, ale specjalizujące się w danej miejscowości właśnie w śpiewach i modlitwach. Takie „śspiewaczki” są zapraszane na większość ceremonii pogrzebowych i pełnią funkcję, którą można porównać do roli płaczki, z tą różnica, że nie płaczą, tylko śpiewają i modlą się 9 .

W dużych miastach nie ma takiego obrzędu jak tutaj, my organizowaliśmy taki dom pogrzebowy w pełni, $\mathrm{w}$ tej chwili nowi przedsiębiorcy pogrzebowi budują kaplice pogrzebowe. Jest to trochę monstrualne, z przesłaniem kościelnym, duże, wielkie, bogate, ale trochę chłodne. (...) Dom pogrzebowy powinien przypominać warunki domowe trochę... (...) Śpiewaczki zaczynają śpiewać. U mnie pracował taki pan (...), on miał zeszyt z tymi pieśniami. One mają swoje pieśni i jest też śpiewnik żałobny, w Internecie można znaleźć. (...) Są też regionalne pieśni, jak się wsłuchać w te pieśni, to jest to taka opowieść o życiu, o modlitwie, tak jak w normalnych piosenkach, jeśli zapamiętamy jedną frazę, to słyszymy jedną frazę, jeśli przesłuchamy całe piosenki, to słyszymy więcej. [wywiad 15, Podlasie, miasto średniej wielkości]

\section{Z kolei na podlaskich wsiach pogrzeby są jeszcze} bardziej tradycyjne i tak jak dawniej są wydarzeniem skupiającym nieraz całą społeczność, całą wieś. Tradycyjnie pożegnanie zmarłego dzieli się na

\footnotetext{
${ }_{9}^{9}$ Wbrew temu, co pisała Anna E. Kubiak w książce Pogrzeby to nasze życie (2015: 117), z moich badań wynika, że grupy śpiewaków pogrzebowych nie są wcale tak rzadko spotykane. Na Podlasiu i Podhalu, szczególnie na wsi, śpiewaczki i śpiewacy są jeszcze osobami praktycznie niezbędnymi podczas czuwania i na pogrzebie. W trakcie wywiadu przeprowadzanego z właścicielem podlaskiego zakładu byłam świadkiem śpiewów podczas czuwania w kaplicy domu pogrzebowego, co według mojego rozmówcy jest bardzo częstą praktyką w tych okolicach.
}

trzy etapy - trzy stacje. Rola zakładu pogrzebowego jest w tym przypadku ograniczona. $W$ tym regionie bardzo często to właśnie rodzina zajmuje się zmarłym, a przynajmniej jest przy nim ciągle obecna.

Na wsiach wygląda to trochę inaczej, ciało jest wystawiane $\mathrm{w}$ domu, zmarły chowany jest na trzecią dobę, po śmierci już od pierwszego dnia schodzą się znajomi, rodzina, sąsiedzi. (...) W naszym podlaskim rejonie są tak zwane śpiewaczki, jest to kilka gospodyń, które siadają w pokoju, gdzie stoi ciało, albo w sąsiednim pokoju, przy jakimś stole, w zależności od sytuacji domowej. Są stawiane soki, herbata, czasem jakieś ciasta, oni mają swoje zeszyty i śpiewają 2-3 godziny, w tym czasie jest odmawiany również różaniec, koronka z przerwami, później około godziny dwudziestej następuje zakończenie, są jakieś luźne rozmowy. (...) Tak, jakby ktoś zmarł w nocy, to by jeszcze było dzisiaj, jutro i na trzeci dzień z reguły jest wyprowadzenie ciała. (...) Na trzeci dzień przywożony jest ksiądz z danej parafii, tak zwana pierwsza stacja się odbywa w domu żałoby, idą konduktem do krzyża, znowu śpiewają, modlą się. (...) Potem jest kondukt karawanem do kościoła, jak jest blisko kościół, to cały czas idą pieszo, jak jest 3-4 kilometry, to już jadą. (...) Jeszcze wrócą do domu, ciało jest wynoszone przed dom, stawiane na taboretach i ksiądz wygłasza tak zwaną mowę pogrzebową. (...) Jest tak zwana trzecia stacja, pierwsza jest $\mathrm{w}$ domu zmarłego, druga jest w kościele, trzecia stacja jest na cmentarzu. [wywiad 15, Podlasie, miasto średniej wielkości]

Według moich rozmówców pogrzeby świeckie zdarzają się na Podlasiu bardzo rzadko, szczególnie w średnich i mniejszych miejscowościach.

Zdarzają się też pogrzeby świeckie, rzadko, ale się zdarzaja. (...) Świecki jeden na rok się trafi. [wywiad 15, Podlasie, miasto średniej wielkości] 
Podlasie jest więc regionem, w którym zmiany w obrzędowości pogrzebów są niewielkie, ale widoczne jest poszerzenie kompetencji przedsiębiorców pogrzebowych, którzy przejmują coraz więcej czynności z rąk rodziny. Niewielka jest liczba kremacji, a „,czuwanie" przy zwłokach przeniesione zostało z domu rodzinnego do zakładu pogrzebowego. Na wsi rodzina poświęca zwykle znacznie więcej czasu na pożegnanie ze zmarłym, co równocześnie oznacza, że zakład pogrzebowy może mieć mniej obowiązków niż $w$ innych miejscach. Tak jak wspomniał jeden z moich rozmówców, na wsi jest to „usługa z dowozem”, zakład pogrzebowy dostarcza ciało zmarłego do domu, a potem odwozi na cmentarz i w zasadzie głównie do tego ogranicza się jego rola. Prawdopodobnie dlatego wielu przedsiębiorców na Podlasiu decyduje się na budowę kaplic przy swoich domach pogrzebowych. Dzięki temu, że zmarły przez większość czasu jest „pod opieką" firmy pogrzebowej, przedsiębiorcy przejmują więcej obowiązków z rąk rodziny, a zarazem może zwiększyć się ich dochód z organizacji ceremonii pogrzebowej. Jak już wcześniej wspomniałam, Podlasie charakteryzuje się również wysoką religijnością mieszkańców oraz dużym wpływem Kościoła na życie społeczne; w przypadku tego regionu niewątpliwie nie tylko Kościoła katolickiego, ale również prawosławnego. Prawdopodobnie to właśnie historycznie niewielka mobilność ludności w tym regionie oraz dość wysoka religijność mają wpływ na bardzo tradycyjny charakter podlaskich pogrzebów.

\section{Podkarpacie}

Podkarpacie wciąż można uznać za tradycyjny region, wydaje mi się jednak, że stosunkowo mała (według moich respondentów) liczba kremacji może być spowodowana małą liczbą krematoriów oraz kosztami przewozu. Komunikacja między wsiami i miastami jest utrudniona ze względu na wąskie i często korkujące się drogi, co może komplikować i wydłużać czas przewozu zwłok. Poza tym Podkarpacie charakteryzuje wysoki poziom religijności mieszkańców - w diecezji rzeszowskiej w 2014 roku odnotowano 64,6\% dominicantes (18,1\% communicantes), w przemyskiej 59,6\% dominicantes (16,5\% communicantes), co daje jeden z najwyższych wyników w Polsce (ISKK 2014). Ponadto z przeprowadzonych przeze mnie badań wynika, że Kościół ma duży wpływ na przebieg ceremonii pogrzebowych, które w dalszym ciągu są tradycyjne, szczególnie na wsiach. Na wsi zakład pogrzebowy ma również mniej obowiązków, nadal to rodzina często ubiera i myje zmarłego. Zdarza się, że zmarły jest w domu aż do pogrzebu, a rodzina i znajomi przychodzą na czuwanie przez trzy dni. W wielu wsiach buduje się już jednak chłodnie, gdzie można przetrzymać ciała aż do pogrzebu, a czuwanie odbywa się w domu, jednak bez ciała zmarłej osoby. Jeśli na wsi jest duża kaplica, to czuwanie odbywa się w kaplicy.

Niejednokrotnie rodzina sama ubiera zmarłego i wtedy my przyjeżdżamy z trumną, jeżeli w danej wsi jest kaplica z chłodnią, to zabieramy do chłodni, zdarza się też, że zostawiamy w domu. Ludzie kiedyś sobie wmówili, że jeśli pod trumną postawią wodę w miednicy, to coś pomoże, pomoże to tak jak umarłemu kadzidło, ale rodzina jest uspokojona. (...) $\mathrm{Na}$ wsiach jest praktykowane to, że schodzi się najbliższa rodzina, przyjaciele, znajomi codziennie przez dwa trzy dni przed pogrzebem i robią tak zwany różaniec zmarłemu, trwa to jakieś pół godziny, w każdej wsi jest prowadząca ten różaniec, niejednokrotnie są to śpiewy. Jak jest większa kaplica, to w tej kaplicy robią różaniec, jeżeli jest mała kaplica, to do chłodni się wstawia, a w domu bez zmarłego jest różaniec. [wywiad 5, Podkarpacie, duże miasto] 
Niewielka liczba kremacji, szczególnie na wsi, jest również związana z pewną niechęcią księży katolickich oraz zarządzeniem Episkopatu Polski, które nakazywało odprawienie mszy przed spopieleniem ciała. Z kolei prawo kanoniczne kremacji również nie zakazuje, lecz „usilnie zaleca” grzebanie ciał zmarłych. W praktyce stosowanie się do zarządzenia Episkopatu oznacza, że często pogrzeb rozciąga się na dwa albo więcej dni, ponieważ wielu księży nie zgadza się na odprawienie mszy nad urną.

Obrzędy pogrzebowe z Mszą Świętą i z ostatnim pożegnaniem włącznie, w których uczestniczy rodzina, wspólnota parafialna, przyjaciele i znajomi, powinny być celebrowane przed kremacją ciała ludzkiego. Natomiast po spopieleniu zwłok sprawuje się obrzęd związany ze złożeniem urny w grobie. Obrzędy pogrzebowe $\mathrm{z}$ ostatnim pożegnaniem należy celebrować w kościele lub kaplicy cmentarnej, bądź w pomieszczeniu krematorium według form podanych w księdze liturgicznej zawierającej Obrzędy pogrzebu. [Konferencja Episkopatu Polski 2011]

Zgodnie z tym postanowieniem Kościół zezwala na kremację, ,jeśli nie podważa wiary w zmartwychwstanie ciała" (KKK 2301, KPK kan. 1176 § 3). Kościół nadal jednak zaleca i popiera „biblijny zwyczaj grzebania ciał zmarłych" (Konferencja Episkopatu Polski 2011).

Okazuje się, że na Podkarpaciu księża często zniechęcają wiernych do kremacji, czasem nawet budując $w$ nich poczucie, że kremacja może być niezgodna $\mathrm{z}$ wiarą oraz polską tradycją. Kremacje są częstsze w mieście niż na wsi, gdzie pogrzeb z urną jest w dalszym ciągu wielkim wydarzeniem, które na długo zostaje w pamięci miejscowych.

Nie, jeżeli by się to zdarzyło, to $w$ takich małych skupiskach ludzi, oni by na językach byli dość długo, dzi- siaj mamy 2016 rok, w miejscowościach, gdzie nigdy nie było pogrzebu z urną, to jak się taki pogrzeb pojawi, to jest gadania przez dwa miesiące. (...) Oprócz tego hamulcem w kremacji są księża, księżom uciekają pieniądze, dzisiaj Kościół opiera się na pieniądzach, coraz więcej ludzi robi tu pogrzeby świeckie, bez księdza i im pieniądze uciekają. Znaleźli sposób na to, jeśli ktoś ma być skremowany, to robią mszę pożegnalną przy trumnie, z ciałem, a potem robią pogrzeb z urną. Następnego dnia albo za dwa dni. (...) Generalnie Kościół nie ma nic do kremacji, ale między wierszami na kazaniu powiedzą coś, co da do zrozumienia ludziom, że to nie jest dobre. (...) Z tymi kremacjami na wsiach jest bardzo opornie i podejrzewam, że jeszcze dziesiątki lat musi minąć, żeby kremacje były na porządku dziennym na wsiach. [wywiad 5, Podkarpacie, duże miasto]

Tutaj na Podkarpaciu to nie jest tak powszechne, jak nie ma miejsca $\mathrm{w}$ grobie rodzinnym, to się decyduja. Teraz jest trochę częściej, bo krematorium tu u nas jest, w Rzeszowie, to częściej się decydują na kremację i dochowanie do grobu rodzinnego niż wcześniej, ale to i tak jest... Ale boją się, że ksiądz nie będzie chciał przyjść, tylko to się rozłoży na cały dzień, albo na dwa dni. [wywiad 7, Podkarpacie, duże miasto]

W podkarpackich miastach pogrzeby są też, poza tym, że mniej tradycyjne, o wiele krótsze niż na wsi. Spotkałam się ze stwierdzeniem, że jest to „masówka". Kremacja na wsi jest również droższa ze względu na konieczność dowozu ciała do krematorium, które często jest bardzo daleko. Oznacza to, że koszt pogrzebu z urną na wsi nie różni się zbytnio od kosztu pogrzebu z trumną (który z reguły jest droższy).

Całkiem inaczej ma się rzecz w mieście, w mieście większość ludzi umiera w szpitalach, hospicjach, tu 
rodzina już nie ma takiej możliwości, żeby takiego zmarłego zabrać do domu. (...) Tu jest całkiem inne podejście niż na wsiach. Na wsiach, jeśli pogrzeb jest o czternastej, to nieraz każą nam na dwunastą trzydzieści zmarłego przywieźć i ta trumna stoi w kościele, a tu jest masówka. (...) Tu pogrzeb ma trwać pół godziny, 40 minut, potem następny wchodzi, tu nie ma czasu na ten różaniec, nie ma ludzi, którzy go poprowadzą. [wywiad 5, Podkarpacie, duże miasto]

Rozmawiałem z księżmi z tego zakątku, bo księża chcą zrobić pogrzeb w kościele z trumną i tak dalej, później ja zabieram ciało i jadę do kremacji, tylko, wie pani, to jest 200 kilometrów w jedną stronę, to jest dwanaście godzin. Tutaj nie ma problemu, normalne pogrzeby się odbywają, jest wniesiona trumna do kościoła i normalny katolicki pogrzeb. Byłoby taniej, gdyby kremacja była bliżej. Trzeba trumnę kremacyjną, później urna i spopielenie. [wywiad 9, Podkarpacie, wieś]

U nas pogrzeby są co godzinę, wychodzi jeden pogrzeb i jest dosłownie 10-15 minut do rozpoczęcia następnego pogrzebu. [wywiad 7, Podkarpacie, duże miasto]

Mimo znacznego skrócenia ceremonii w miastach, pogrzeby świeckie odbywają się rzadko. Według przedsiębiorców, z którymi rozmawiałam, ceremonie bezwyznaniowe nie dotyczą ateistów, tylko osób, które w przeszłości obraziły się na księdza czy Kościół. Mimo braku księdza, który zastępowany jest mistrzem ceremonii, na takich pogrzebach ludzie często się modlą.

Ten pan po prostu nie był dopuszczony do pierwszej komunii, był rozrabiaka. $\mathrm{W}$ tym dniu, kiedy była komunia, poszedł na tą plebanię, bo wszyscy poszli, ksiądz go zobaczył i wypędził. Od tego czasu miał w dupie księży, za przeproszeniem. Miał pogrzeb świecki, miał 79 lat i pamiętał, że go ksiądz wygonił, nie dał mu tej bułki z tym kakao. [wywiad 7, Podkarpacie, duże miasto]

Dwa do roku, to prowadzi celebrant. To wychodzi drogo, bo najbliższy jest w Rzeszowie i on jak przyjeżdża, to przywozi od razu skrzypka z Filharmonii Rzeszowskiej i przepięknie to wygląda. Ta celebra to nie jest odsunięcie od Boga, po prostu jest chwila, żeby się pomodlić. [wywiad 9, Podkarpacie, wieś]

Można odnieść wrażenie, że Podkarpacie to region bardzo tradycyjny, jednak biorąc pod uwagę szybkie i masowe pogrzeby w miastach, wydaje się, że zmierza do bycia mniej tradycyjnym niż Podlasie. Być może w wielu podkarpackich wsiach zachowane są jeszcze dawne tradycje i zwyczaje pogrzebowe, ale $\mathrm{w}$ trakcie badań odniosłam wrażenie, że często spowodowane jest to raczej brakiem innych możliwości - na przykład cena pogrzebu z urną nie jest bardziej przystępna niż pogrzebu z trumną oraz z brakiem zgody księdza, który ma znaczący wpływ na przebieg ceremonii pogrzebowych. Co ciekawe, jest to region z najniższym wskaźnikiem urbanizacji w Polsce, ludność miejska stanowi jedynie 41\% ogółu ludności województwa (średnia dla Polski to 60,3\%), a co ciekawsze, mieszkańcy Podkarpacia bardzo chętnie migrują z miast do wsi w obrębie województwa (Urząd Statystyczny w Rzeszowie 2016). Może to oznaczać, że odchodzenie od tradycji będzie postępowało wolniej, jeśli założymy, że to miasta dyktują obyczaje dla danego regionu, a na wsi przyjmują się one w dużo wolniejszym tempie. Z kolei ludność przybyła z miast może też wprowadzać nowe zwyczaje na wsi. Nie widać cech, które wskazywałyby na pełną profesjonalizację przedsiębiorstw pogrzebowych (na przykład przeniesienie czuwania do domu pogrzebowego, przejęcie 
wszystkich czynności związanych z organizacją pogrzebu z rąk rodziny); w trakcie badań zaobserwowałam raczej, że są one podobne do zakładów na Pomorzu Zachodnim czy w Warszawie. Przedsiębiorcy $z$ branży funeralnej nie budują przy swoich zakładach wielkich kaplic czy domów pogrzebowych. W Rzeszowie ceremonie są coraz krótsze, pożegnanie w kaplicy ogranicza się do kilkunastu minut, nie ma czuwania, nie ma trumny w domu. Coraz bardziej powszechne stają się też kremacje. Można założyć, że gdyby nie postawa księży wobec tego sposobu pochówku oraz zła jakość podkarpackich dróg, kremacje wkrótce byłyby bardziej powszechne także na wsi.

\section{Podhale}

Podhale to region, który należy zaliczyć do bardzo tradycyjnych. Górale podhalańscy są bardzo charakterystyczną i wyróżniającą się grupą, która wykształciła własne zwyczaje i tradycje. Jednak nawet tam widoczne jest odchodzenie od tradycji, zwłaszcza w Zakopanem. Można to jednak łatwo powiązać z napływem ludności spoza województwa do Zakopanego, które jest dla wielu osób atrakcyjnym miejscem do zamieszkania. Podhale charakteryzuje także wysoki poziom religijności mieszkańców (ISKK 2014) ${ }^{10}$, który przejawia się również w małej liczbie pogrzebów świeckich. Kremacje wśród podhalańskich górali są bardzo mało powszechne, chociaż już się zdarzają. Przedsiębiorcy pogrzebowi, z którymi

\footnotetext{
${ }^{10}$ Dane Instytutu Statystyki Kościoła Katolickiego z 2014 roku pokazują procent dominicantes i communicantes dla poszczególnych diecezji; Podhale znajduje się na obszarze diecezji krakowskiej, dlatego w tym przypadku procenty mogą być zaniżone. Dla całej diecezji krakowskiej odsetki wynoszą odpowiednio 50,7\% i 17,7\%, czyli znacznie więcej niż dla diecezji warszawskiej (30,4\% i 14,6\%) czy szczecińsko-kamieńskiej (24,9\% i $11,3 \%$ ). Z kolei sąsiadująca z Podhalem diecezja tarnowska odnotowała najwyższą liczbę dominicantes i communicantes w całej Polsce: $70,1 \%$ i $24,3 \%$.
}

rozmawiałam, twierdzili, że kremacji wciąż jest bardzo mało (co najwyżej około $10 \mathrm{w}$ roku). Być może ma to związek nie tylko $z$ tradycjami regionu, ale i z faktem, że najbliższe krematorium znajduje się w Krakowie, co oznacza, że koszty kremacji są bardzo duże w porównaniu z tymi kosztami w dużych miastach, które dysponują własnym krematorium. Częstym motywem wyboru kremacji w Zakopanem jest również możliwość dochowania do grobu. W podhalańskich wsiach pogrzeby w dalszym ciągu są bardzo tradycyjne, z czuwaniem w domu, śpiewami i modlitwami.

Natomiast zdarzają się już wśród górali kremacje, to jest taki krok naprzód. (...) Tutaj na Nowotarskiej nie ma już miejsca na cmentarzu, nowy jest na Pardałówce i też nie każdy chce. Stąd te kremacje tych, co tu mają [groby - przyp. MS], nie chcą rozdzielać, bo część rodziny tu, a część gdzie indziej. Również zdarzają się ekshumacje i do kremacji także. To już są względy ekonomiczne, ilością tego miejsca, brakiem. No i kolumbarium zrobili, to też ludzie się na to decydują. (wywiad 11, Podhale, miasto średniej wielkości]

Tutaj mało, w roku mamy dziesięć. Za życia sobie życzą, by być skremowani. W Zakopanem dużo jest więcej kremacji tylko ze względu na to, że cmentarza już nie ma i jest dochowanie. [wywiad 10, Podhale, duże miasto]

Straszna rzadkość, kremacja, już Zakopane tak, więcej, Nowy Targ już więcej jest kremacji, a tutaj nie. Jeździłem na kremacje nieraz, ale to osoby takie kremowaliśmy, co nie pochodziły stąd i też nie były tu chowane. (...) Lub pochowaliśmy, ale ze Stanów Zjednoczonych przychodziła urna, zza granicy, Polaków. (...) Często też jest wykonywana kremacja z bardzo prostego powodu, braku miejsca na cmentarzu. [wywiad 12, Podhale, wieś] 
Tradycyjne pożegnanie zmarłego na Podhalu, we wsiach, w których mieszka jednak większość mieszkańców tego regionu, trwa jeszcze czasem kilka dni. W zależności od stanu rozkładu ciała zmarły leży w domu lub, gdy jest to niemożliwe, zawozi się ciało do chłodni, a zamiast tego w domu stawia się zdjęcie zmarłego. Przez dwa - trzy dni do domu przychodzą znajomi, sąsiedzi i rodzina, codziennie wieczorem, po mszy, modlą się i śpiewają. Tak jak na Podlasiu, tu również funkcjonuje instytucja śpiewaczki pogrzebowej. Zwykle we wsi jest kilka takich osób, najczęściej kobiet, które znają pieśni pogrzebowe i są wzywane na każde czuwanie i pogrzeb. Trumna stoi w domu na katafalku lub na taboretach, po bokach zapala się dwie świece, często wkłada się do trumny różne przedmioty, takie jak książeczka do nabożeństwa czy różaniec. Również i tutaj, tak jak na Podlasiu, są trzy stacje, w domu, w kościele i na cmentarzu. Pogrzeb wiejski często trwa nawet pół dnia, w zależności od wielkości wsi i odległości z domu do kościoła. Kondukt często jeszcze idzie na piechotę, jednak już zdarza się, że starsi ludzie są wożeni samochodami. Przedsiębiorca pogrzebowy, który prowadzi interes na wsi, stwierdził, że czas ceremonii jest dużo dłuższy niż w miastach ze względu na to, że pochówków jest dużo mniej niż w mieście. Również ze względu na to, że wszyscy ludzie we wsi się znają, pogrzeb jest dużym wydarzeniem i musi zajmować więcej czasu niż tylko pół godziny pożegnania i odprowadzenie na cmentarz.

W porównaniu do pogrzebów, które widziałem w dużych miastach, to jest przepaść. (...) W dużych miastach to jest pogrzeb 20 minut i się kończy, jest kaplica i już następny w kolejce. A tutaj niekiedy godzinę przed są modlitwy, różańce, później jest wyprowadzenie z domu, zdarza się, że niekiedy półtorej godziny, dwie godziny, że jest kondukt, że jest słoń- ce, a dochodzimy, jak jest burza i deszcz. I wszyscy tak samo idą, i starsi, i młodzi. Później jest godzina mszy. (...) Modlitwy, przychodzi ksiądz do domu, żegna zmarłą osobę, pożegnanie, jest taki obrządek. (...) Tak jak jest zmarła osoba, jeżeli jest, bo nawet, jeśli jej nie ma, to wykonujemy takie zdjęcie, palą się świece i średnio około godziny trwają modlitwy co wieczór, zazwyczaj jest to po mszach wieczornych, czyli osiemnasta-dziewiętnasta $\mathrm{w}$ domu. I to jest codziennie, aż praktycznie do pogrzebu. (...) I na cmentarzu znowu jest to samo, znowu są modlitwy za tych, co spoczywają na cmentarzu, niekiedy są śpiewy. (...) Jest to społeczność jakby zżyta, znająca się, niż po miastach czy dużych miejscowościach. Czasem $\mathrm{w}$ jednym takim bloku w mieście mieszka taka cała wioska. [wywiad 12, Podhale, wieś]

Z kolei w większych podhalańskich miejscowościach raczej odchodzi się już od trzymania zmarłego w domu przez kilka dni (chociaż jeszcze się to zdarza). Pożegnanie ogranicza się już tylko do odprawienia różańca przed pogrzebem. Nie oznacza to jednak, że górale rezygnują z tradycyjnej oprawy. Są to ceremonie bardzo bogate, często z orkiestrą, śpiewami, w tradycyjnych ubraniach, tak zwanych cuchach ${ }^{11}$. W miastach na Podhalu przedsiębiorcy pogrzebowi też już coraz częściej przejmują praktycznie wszystkie obowiązki z rąk rodziny.

Tak modlą się wieczór na przykład w góralskich domach, jest tak, że modlą się $w$ domu i to, czy zmarły jest $\mathrm{w}$ tym domu, czy nie, ale przychodzi rodzina, znajomi i wszyscy modlą się w tym domu. Natomiast w Zakopanem jest inaczej, modlitwa jest w kościele. (...) Jak mówimy o tych tradycyjnych, to

\footnotetext{
${ }^{11}$ Cucha to wierzchnie okrycie męskie noszone przez górali, wełniane i zdobione.
} 
bardziej o wsi. Tak. Tutaj zazwyczaj modlitwa jest w kaplicy. (...) Przeważnie nie leży, teraz już tak nie ma, kiedyś było. Teraz przywozi się zmarłego przed pogrzebem, tak że to nie ma już tak, jak kiedyś. (...) Oczywiście w Zakopanem najczęściej skrzypce, trąbka, a jeżeli jest góralski pogrzeb, to jest orkiestra, kapela góralska. [wywiad 11, Podhale, miasto średniej wielkości]

Podobnie jak $\mathrm{w}$ innych regionach na Podhalu pogrzeby świeckie wciąż są rzadkością. Według moich rozmówców na ceremonię bez księdza decyduje się rodzina, jeśli takie było życzenie zmarłego. Podobnie jak $\mathrm{w}$ innych regionach $\mathrm{w}$ zdecydowanej większości nie jest to podyktowane brakiem wiary, tylko nieporozumieniami z duchownymi.

Zdarzają się, ale też jeszcze rzadziej niż innych wyznań. Może po tych większych miastach, a u nas przez piętnaście lat zdarzyło się może pięć pogrzebów [świeckich - przyp. MS]. [wywiad 11, Podhale, miasto średniej wielkości]

Podhale jest bardzo tradycyjnym regionem, jeśli chodzi o pogrzeby. Być może w jakimś stopniu jest to spowodowane przewagą ludności wiejskiej nad miejską (współczynnik urbanizacji dla Małopolski wynosił 48,5\% w 2015 roku, przy średniej 60,3\% dla kraju, natomiast $\mathrm{w}$ powiatach, $\mathrm{w}$ których robiłam badania, tatrzańskim i nowotarskim, wynosił odpowiednio 40,4\% i 27,5\%) (Urząd Statystyczny w Krakowie 2016) oraz głęboko zakorzenionymi tradycjami góralskimi. Pochówki z urną są w tym regionie rzadkością, wydaje się nawet, że jeśli trafi się kremacja raz na kilka lat, to ludzie bardzo długo o tym pamiętają i mówią. Mieszkańcy Podkarpacia są ludźmi bardzo religijnymi. Ponieważ śmierć w mniejszych społecznościach wiejskich jest, siłą rzeczy, wydarzeniem dużo rzadszym od śmierci w dużym mieście, pogrzeby w naturalny sposób stają się rozciągniętymi niekiedy na pół dnia wydarzeniami, w których uczestniczą całe wiejskie społeczności. W takich wsiach naturalnie wszyscy się znają, więc niemal każdy przychodzi pożegnać zmarłego. Górale podhalańscy są na tyle odrębną grupą z podtrzymywanymi, zarówno z pokolenia na pokolenie, jak i ze względu na wartość turystyczną, tradycjami, że trudno jest mówić o wielkich zmianach i prognozach na przyszłość. Zmiany, które zaobserwowali moi respondenci, dotyczyły głównie względów praktycznych (takich jak kremacje z powodu braku miejsca na cmentarzu) lub związane były z upowszechnieniem się technologii (na przykład katafalk zamiast stołków czy samochód $\mathrm{w}$ kondukcie pogrzebowym). Z pewnością $\mathrm{w}$ miastach tradycja jest mniej obecna niż na wsi, należy jednak zauważyć, że w miastach takich jak Zakopane mieszka dużo ludności napływowej, niezwiązanej wcześniej z tym regionem i niepowielającej miejscowych tradycji.

\section{Warszawa i okolice}

Ponieważ badania, które prowadziłam w Warszawie i okolicach, nie dotyczyły zwyczajów funeralnych, tylko funkcjonowania przedsiębiorstw pogrzebowych, nie dysponuję dokładnymi opisami pogrzebów. W moich wywiadach były jednak poruszane kwestie, które interesują mnie w tym artykule, takie jak kremacje, dlatego postanowiłam opisać także i ten region. Warszawa charakteryzuje się również dosyć niską religijnością mieszkańców - w danych z 2014 r. $\mathrm{w}$ diecezji warszawskiej dominicantes i communicantes stanowili odpowiednio 30,4\% i 14,6\%, a w diecezji warszawsko-praskiej 31,4\% i 14,3\% (ISKK 2014). W Warszawie jest stosunkowo dużo kremacji, co spowodowane jest po części niższymi kosztami takich pochówków (które w Warszawie w ogóle są dosyć 
wysokie) oraz również brakiem miejsc na cmentarzach. Poza tym pogrzeby są podobne do szczecińskich, zakład pogrzebowy zajmuje się załatwieniem wszystkich formalności, a rodzina i znajomi żegnają się ze zmarłym krótko, w dniu pogrzebu, zwykle w przycmentarnej kaplicy (własna obserwacja).

To znaczy tak, generalnie, jeśli chodzi o kremacje, to nie jest ich mniej. Dlatego przybyło tych krematoriów w Polsce, bo zapotrzebowanie na kremacje wzrosło. I to lawinowo rośnie. W tej chwili w Warszawie nawet bym powiedział, że nawet więcej niż jedna trzecia, ale trzeba by było mieć dostęp do takich statystyk, żeby to sprawdzić. Ale ze swojej obserwacji, z ilości, tak mniej więcej proporcji pogrzebów tradycyjnych, a po kremacji, to już widzę, że $w$ tej chwili to jest mniej więcej jedna trzecia pogrzebów, o ile nie więcej. (...) No, może w miastach dużych to jeszcze jest to spowodowane tym, że, no, miejsca grzebalne są bardzo drogie na cmentarzach, a urna, no, jest, nawet jeśli ma się jakiś grób rodzinny, który jest zajęty, zawsze można tę urnę dochować, zawsze w takim miejscu, jak się ma taki grób rodzinny, to tych urn można dochować wiele. (...) Tak że tutaj też te względy finansowe na pewno. [wywiad 22, Warszawa]

Również w okolicach Warszawy jest sporo kremacji (w porównaniu z bardziej tradycyjnymi regionami), nawet $\mathrm{w}$ małych miejscowościach. Motywy wyboru kremacji są zwykle takie same jak w Warszawie, chodzi o niższą cenę oraz miejsca na cmentarzu. Zasiłek pogrzebowy, zgodnie z ustawą o emeryturach i rentach, od 2011 roku wynosi 4000 zł (Dz.U. z 2016 r. poz. 887, z późn. zm.), co jest zbyt małą sumą na organizację pogrzebu w Warszawie, jest to jednak kwota wystarczająca na pogrzeb w małej miejscowości pod Warszawą.

Proszę panią, jak to pani powiedzieć. Trzy czwarte to są pogrzeby, $25 \% \mathrm{z}$ tego to jest kremacje. $\mathrm{W}$ tym mie- siącu chyba zrobiłem 3 kremacje. Dlaczego się ludzie kremują? Zasiłek pogrzebowy wynosi 4000. Koszt kupienia grobu, przykładowo tu u nas, jest 800 do 1000 złotych. (...) Ale jeśli przyjdzie się pochować tego biednego na Wólce, (...) 7200 to kosztują te miejsca, które są blisko drogi. Blisko zarządu cmentarza. Blisko wejścia. Natomiast gdyby pani kupiła gdzieś tam dalej w głębi, to w głębi te groby kosztują taniej, bo tam będzie chyba nie 7200, ale 6400, może 5600. Nie wiem już, to tam ceny to $\mathrm{z}$ dnia na dzień, wie pani, co rok to jest nowa cena. [wywiad 26, wieś pod Warszawą]

Kremują się ze względu na koszty, finanse. O grób przeważnie chodzi też. Wie pani, nowy grób to jest kilka tysięcy kosztu, do tego koszt pomnika, takie rzeczy. A do grobu, w którym już ludzie mają pochowanych zmarłych, swoich można dołożyć... Całe pokolenia. [wywiad 24, miasto średniej wielkości pod Warszawą]

Z kolei w miejscowościach bardziej oddalonych od Warszawy wydaje się, pogrzeby są bardziej tradycyjne oraz mniej jest kremacji. Być może wynika to $\mathrm{z}$ takiej zależności, jak $\mathrm{w}$ innych regionach, że im dalej od miasta oraz im mniejsza miejscowość, w której więcej ludzi się zna, tym bardziej tradycyjne i dłuższe są ceremonie.

Tutaj jest rynek ludzi, tu to tradycjonaliści żyją. Oni mało kremacji, oni pogrzeb tradycyjny. Jest inaczej mimo wszystko. A tak jak mówiłem, większość to koszty, jeśli chodzi o kremacje. [wywiad 24, miasto średniej wielkości pod Warszawą]

W Warszawie coraz częściej zdarzają się pogrzeby świeckie, bez udziału księdza, za to z mistrzem ceremonii. Z badań Anny E. Kubiak (2015: 223) wynika, że w Warszawie odbywa się około 60 świeckich pogrzebów na miesiąc. Respondenci wskazują różne przyczyny wyboru takiego rodzaju ceremonii, 
ale tak jak w innych regionach bardzo często na takich pogrzebach odmawiana jest modlitwa, a na trumnie jest krzyż.

Tak jest. Proszę panią, są pogrzeby świeckie, na których się ludzie modlą. To wszystko zależy od mistrza ceremonii. Zależy od rodziny, bo to rodzina w sumie jest przy organizowaniu tego pogrzebu. Jeżeli mają takie życzenie. Są pogrzeby świeckie, które, proszę panią, jest krzyżyk na trumnie, jest krzyżyk na tabliczce, bo ludziom to nie przeszkadza. Nie chcą tylko księdza. $Z$ różnych powodów. [wywiad 20, Warszawa]

Z zebranych przeze mnie relacji przedsiębiorców pogrzebowych z Warszawy oraz z obserwacji wynika, że Warszawa, w porównaniu z innymi regionami, jest mało tradycyjna, jeśli chodzi o pogrzeby. Prawdopodobnie wynika to z faktu, że jest to duże miasto, w którym mieszka bardzo dużo napływowej ludności z całej Polski. Oczywistym faktem jest również masowość pochówków w dużym mieście, co przyczynia się do skrócenia czasu przeznaczonego na poszczególne ceremonie. Można porównać pogrzeby warszawskie do pogrzebów w Szczecinie. Są wykonywane równie szybko, nie ma czuwania przy zmarłym w domu. Pożegnanie ogranicza się do 15-30 minut w kaplicy przycmentarnej, po czym następuje odprowadzenie trumny lub urny na cmentarz. Kremacje są w Warszawie coraz bardziej popularne, jest ich zdecydowanie więcej niż na Podlasiu czy Podkarpaciu (nawet $\mathrm{w}$ największych miastach wojewódzkich). Coraz więcej rodzin decyduje się na spopielenie zwłok ze względów finansowych oraz braku miejsca na cmentarzach. Być może wkrótce kremacje staną się jeszcze bardziej popularne, co wydaje się nieuniknione, biorąc pod uwagę ograniczenia związane $\mathrm{z}$ brakiem miejsc na warszawskich cmentarzach, bo mimo przepisów, zgodnie z którymi po kilkudziesięciu latach likwiduje się nieopłacone groby, miejsca ciągle jest za mało. Pogrzeby są też bardziej prywatnym wydarzeniem, w dużych miastach bardzo rzadko przyciągają uwagę całych społeczności. Przedsiębiorstwa pogrzebowe w Warszawie to miejsca, w których rodzina załatwia sprawy związane z pochówkiem. Pogrzebownicy załatwiają za rodzinę praktycznie wszystko, od umówienia księdza czy mistrza ceremonii, przez formalności w ZUS-ie, po złożenie ciała lub urny do grobu. Czas, który rodzina spędza ze zmarłym, jest ograniczony do dnia pogrzebu.

\section{Podsumowanie}

Dobór regionów, w których prowadzone były badania, wydaje się trafny i pozwala pokazać zróżnicowanie pochówków. Można wyróżnić trzy główne czynniki wpływające na tradycyjność pogrzebów. Po pierwsze, religijność mieszkańców (której wskaźnikiem jest odsetek dominicantes i communicantes). Po drugie, wielkość miejscowości (wieś, miasto średniej wielkości, duże miasto). Po trzecie, „zakorzenienie" regionalnej społeczności.

We wszystkich powyższych regionach można zauważyć tendencję odchodzenia od tradycyjnych pochówków w miastach i zachowanie się niektórych obyczajów i tradycji we wsiach. Miejskie pogrzeby są mniej tradycyjne, zajmują mniej czasu i więcej czynności zleca się przedsiębiorcy pogrzebowemu. Dotyczy to praktycznie wszystkich regionów, w których prowadziłam badania. Dzieje się tak z powodu większej anonimowości rodzin wielkomiejskich oraz ze względów praktycznych. Ponadto to w miastach częściej zdarza się, że ludzie umierają w szpitalach czy hospicjach, a nie we własnym domu. Wydaje się również, że w miastach jest po prostu mniej czasu na długie pożegnania ze zmarłymi. „Kolejka” oczekujących na pochowanie jest naturalną konsekwencją liczby zgonów, która jest 
proporcjonalna do liczby mieszkańców. Pożegnanie w większych aglomeracjach jest zdecydowanie krótsze i odbywa się w pośpiechu.

Pewne elementy rytuałów pogrzebowych są zachowane $\mathrm{w}$ szczątkowej postaci, szczególnie $\mathrm{w}$ miastach, ale w dalszym ciągu istnieją, na przykład msza w skróconej wersji czy czuwanie przy zwłokach, które nie odbywa się już na ogół w domu zmarłego, tylko w kaplicy domu pogrzebowego lub przycmentarnej i trwa znacznie krócej.

Okazuje się, że wysoki poziom religijności mieszkańców sprzyja zachowaniu tradycyjnych sposobów grzebania zmarłych. Można zauważyć, że w regionach charakteryzujących się wysokim poziomem religijności pogrzeby są bardziej tradycyjne oraz liczba kremacji jest niższa niż w regionach mniej religijnych. Może być to związane z niechęcią niektórych księży Kościoła katolickiego do pogrzebów urnowych oraz koniecznością dojazdu do krematoriów, niekiedy bardzo oddalonych od miejsca zgonu, co sprawia, że koszty pogrzebu z kremacją rosną. Interesujące jest, że decyzje o kremacji podejmowane są często ze względów praktycznych (z powodu braku miejsca na cmentarzu lub w rodzinnym grobie), a tam, gdzie jest blisko do krematorium, także ze względów finansowych. Nie można jednak lekceważyć faktu, że czynnikiem wpływającym na stosunkowo małą liczbę kremacji jest konserwatywna postawa księży wobec pogrzebów z urną.

Okazuje się, że pogrzeby świeckie są ciągle rzadkością i dotyczy to wszystkich badanych regionów.
Zdarza się, że decyzja o świeckim pogrzebie podejmowana jest $\mathrm{w}$ wyniku zaszłych nieporozumień lub konfliktu z lokalnym kapłanem, ale wtedy zazwyczaj rodzina zmarłego stara się zachować podstawowe elementy pochówku religijnego nawet wtedy, kiedy ksiądz nie uczestniczy w ceremonii.

Skoro pogrzeb, poza oczywistymi funkcjami jawnymi, pełni rozmaite społeczne funkcje ukryte, na przykład pomaga zaakceptować fakt czyjejś śmierci, przyspiesza proces żałoby, pokazuje pozycję społeczną zmarłego czy też integruje społeczność, ważne jest, żeby odbył się zgodnie z przekonaniami, poczuciem estetyki oraz wyznaniem bliskich. Przykładem są tutaj pogrzeby bez udziału księdza i typowej katolickiej oprawy, które mimo tego, że zmarły życzył sobie świeckiej ceremonii, często są okazją do modlitwy za nieżyjącego przy obecnym wszędzie znaku krzyża. Chęć zaakcentowania pozycji społecznej zmarłego poprzez „dochowanie” urny do grobu na prestiżowym cmentarzu jest czasem motywem skłaniającym rodzinę do kremacji. Podobnie pogrzeby tradycyjne, z trumną oraz księdzem, również pełnią funkcje terapeutyczne dla bliskich nieżyjącego poprzez ich przekonanie, że dusza spokojnie przejdzie do zaświatów, jeśli wszystkie religijne rytuały zostaną spełnione.

Wnioski z przeprowadzonego badania wydają się na tyle interesujące, że zachęcają do rozważenia możliwości przeprowadzenia ogólnopolskich badań reprezentatywnych, których celem byłaby analiza regionalnych i społecznych zróżnicowań pochówków i zwyczajów pogrzebowych.

\section{Cytowanie}

Staszyńska Maria (2020) Regionalne zróżnicowanie pochówków w Polsce. „Przegląd Socjologii Jakościowej”, t. 16, nr 4, s. 210-231 [dostęp dzień, miesiąc, rok]. Dostępny w Internecie: «www.przegladsocjologiijakosciowej.org〉. DOI: http://dx.doi.org/10.18778/1733-8069.16.4.11 


\section{Bibliografia}

Ariés Philippe (2011) Człowiek i śmierć. Przełożyła Eligia Bąkowska. Warszawa: Wydawnictwo Aletheia.

Bauman Zygmunt (1998) Śmierć i nieśmiertelność. O wielości strategii życia. Przełożył N. Leśniewski. Warszawa: PWN.

Gajewska Magdalena (2009) Prochy i diamenty. Kremacja ciała zmarłego człowieka jako zjawisko społeczne i kulturowe. Kraków: Nomos.

Hammersley Martyn, Atkinson Paul (2000) Metody badań terenowych. Przełożył Sławomir Dymczyk. Poznań: Zysk i S-ka.

Instytut Statystyki Kościoła Katolickiego (2014) Praktyki niedzielne Polaków [dostęp 17 maja 2017 r.]. Dostępny w Internecie: 〈http://iskk.pl/kosciolnaswiecie/231-dominicantes-2014.html〉.

Konferencja Episkopatu Polski (2011) List pasterski Episkopatu Polski o szacunku dla ciała zmarłego i obrzędach pogrzebu w przypadku kremacji [dostęp 17 maja 2017 r.]. Dostępny w Internecie: ‘http:// episkopat.pl/list-pasterski-episkopatu-polski-o-szacunku-dlaciala-zmarlego-i-obrzedach-pogrzebu-w-przypadku-kremacji/^.

Kubiak Anna E. (2015) Pogrzeby to nasze życie. Warszawa: Wydawnictwo IFiS PAN.

Merton Robert K. (1987) The Focussed Group Interview and Focus Groups. Continuities and Discontinuities. „Public Opinion Quarterly", vol. 51, s. 557-558.

Merton Robert K. (2002) Teoria socjologiczna i struktura społeczna. Przełożyli: Jerzy Wertenstein-Żuławski, Ewa Morawska. Warszawa: Wydawnictwo Naukowe PWN.

Morgan David L. Fellows Collin E. (2008) Focus Group and Public Opinion [w:] W. Donsbach, M. W. Traugott, eds., The SAGE Handbook of Public Opinion Research. Los Angeles, London, New Delhi, Singapore: SAGE Publications, s. 340-347. di Nola Alfonso M. (2006) Tryumf śmierci, Antropologia żałoby. Przełożyli Jolanta Kornecka i in., Kraków: Towarzystwo Autorów i Wydawców Prac Naukowych UNIVERSITAS.

Ostrowska Antonina (2005) Śmierć w doświadczeniu jednostki i społeczeństwa. Warszawa: Wydawnictwo IFiS PAN.

Thomas Louis-Vincent (1991) Trup. Od biologii do antropologii. Przełożył Krzysztof Kocjan. Łódź: Wydawnictwo Łódzkie.

Urząd Statystyczny w Krakowie (2016) Stan i ruch naturalny ludności w województwie Małopolskim w 2015 r. [dostęp 12 maja 2017 r.]. Dostępny w Internecie: 〈https://krakow.stat.gov.pl/ files/gfx/krakow/pl/defaultaktualnosci/1799/1/13/1/7._sygnalna_ludnosc_2016.pdf .

Urząd Statystyczny w Rzeszowie (2016) Stan, ruch naturalny i migracje ludności w województwie Podkarpackim w 2015 r. [dostęp 12 maja 2017 r.]. Dostępny w Internecie: 〈https://rzeszow. stat.gov.pl/dane-o-wojewodztwie/wojewodztwo-879/ludnosc-2013-979/>.

Urząd Statystyczny w Szczecinie (2016) Stan i ruch naturalny ludności w województwie Zachodniopomorskim w 2015 r. [dostęp 12 maja 2017 r.]. Dostępny w Internecie: http://szczecin.stat. gov.pl/files/gfx/szczecin/pl/defaultaktualnosci/1649/1/9/1/stan ruch_ludn_sygn_2015.pdf .

Ustawa z dnia 31 stycznia 1959 r. o cmentarzach i chowaniu zmarłych. Dz.U. 1959 nr 11 poz. 62.

Ustawa z dnia 17 grudnia 1998 r. o emeryturach i rentach z Funduszu Ubezpieczeń Społecznych. Dz.U. z 2016 r. poz. 887, z późn. zm.

Vovelle Michel (2008) Śmierć w cywilizacji Zachodu. Od roku 1300 po współczesność. Przełożyli Tomasz Swoboda i in. Gdańsk: Wydawnictwo słowo/obraz terytoria.

\section{The Regional Diversification of Burials in Poland}

Abstract: The aim of this article is the analysis of regional and social differences in burial ceremonies. It summarizes the results of a qualitative research conducted in five Polish regions: West Pomerania, Podkarpacie, Podlasie, Podhale, and Warsaw with its surrounding. The qualitative data comes from unstructured individual interviews conducted with funeral parlors' owners and their employees. Funeral parlors perform an increasingly important roles in burial ceremonies, while their owners demonstrate sound knowledge of the social expectations towards the organization of funerals.

Keywords: funeral, burial, cremation, funeral home, funeral director, death 